\title{
Efficiency of Various Reagents on Ammonia Reduction in Litter Removal From Belt Conveyors for Battery Cages
}

\author{
A.P. Palii ${ }^{1}$, I.M. Lukyanov${ }^{1}$, A.O. Kovalchuk ${ }^{2}$, S.A. Denicenko ${ }^{1}$, V.S. Kalabska ${ }^{3}$, S.G. \\ ${\text { Ivashchenko' }{ }^{1} \text {, Y. A. Boyko }{ }^{3} \text {, T.O. Sychova }{ }^{1} \text {, P.V. Diachuk }{ }^{3} \text {, T.Y. Mitiashkina }{ }^{1} \text {, A.P. Paliy }}^{4}$ \\ ${ }^{1}$ Kharkiv National Technical University of Agriculture named after Petro Vasylenko, \\ Str. Alchevskih, 44, Kharkiv, 61002, Ukraine. \\ ${ }^{2}$ Ivan Kozhedub Kharkiv National Air Force University, \\ Str. Sumska, 77/79, Kharkiv, 61023, Ukraine. \\ 3 Pavlo Tychyna Uman State Pedagogical University, \\ Str. Sadova, 2, Uman, Cherkassy region, 20300, Ukraine. \\ ${ }^{4}$ National Scientific Center «Institute of Experimental and Clinical Veterinary Medicine», \\ Str. Pushkinska, 83, Kharkiv, 61023, Ukraine. \\ E-mail: paliy.andriy@ukr.net
}

Received 19.11.2019. Accepted 11.12.2019

\begin{abstract}
With the development of technogenic civilization, various anthropogenic factors (ionizing radiation, toxic substances, etc.) affect virtually all living organisms, and often this effect is negative. The current state of affairs on many poultry farms is that they have a negative impact on the surrounding biosphere due to harmful emissions. This is due to the accumulation of litter. The purpose of the study was to investigate the microclimate parameters in the poultry house with the addition of various reagents and zeolite in the belt conveyors of cage batteries. It was proposed to add adsorbents (zeolite) and chemical reagents (phosphogypsum, superphosphate, and aluminium chloride and iron sulphate) directly onto the litter removal belt conveyors of cage batteries. It was found that application of zeolite onto the conveyor belt in an amount of $600 \mathrm{~g} / \mathrm{m}^{2}$ reduces the content of ammonia in the premises by 1.6 times on the first day of accumulation of litter, and by 1.25 times on the seventh day, not exceeding during all seven days of maximum allowable concentrations. However, within all seven days of litter accumulation, a difference in this indicator with control was statistically significant $(P \leq 0.001)$. The reduction of ammonia emissions was less significant when applying a dose of zeolite of $300 \mathrm{~g} / \mathrm{m}^{2}$ conveyor belt: by 1.6 times on the first day of accumulation of litter, and from the fifth day the difference with control was statistically significant. The application of phosphogypsum onto the conveyor belt in the amount of $600 \mathrm{~g} / \mathrm{m}^{2}$ provided a reduction of ammonia emission by 2.1-1.1 times, $300 \mathrm{~g} / \mathrm{m}^{2}$-by 1.8 times on the first day of accumulation of litter. Since the fifth the day, the difference in control was statistically significant. The application of superphosphate onto the litter removal conveyor belts reduced the ammonia content in the poultry house in almost the same extent as when applying phosphogypsum. The effective time of this reagent was also close in importance. Aluminium chloride and ferrous sulphate were used in smaller doses than other absorbents and reagents, but on the initial five days of litter accumulation, they provided a relatively significant reduction in the ammonia content of the air in the poultry house: ferrous sulphate at a dose of $200 \mathrm{~g} / \mathrm{m}^{2}$ of the conveyor belt area - by $2.0-1.2$ times, aluminium chloride - by 4.0-1.5 times. Anyway, the efficacy of these reagents in the last days of litter accumulation was considerably decreased. The use of aluminium chloride and ferrous sulphate in doze of $100 \mathrm{~g} / \mathrm{m}^{2}$ for the conveyor belt provided a proper reduction of indoor ammonia content only for the initial tree-four days.
\end{abstract}

Key words: Microclimate; Poultry litter; Zeolite; Reagent; Ammonia emission

\section{Introduction}

Modern poultry complexes does not produce eggs and poultry only but also of waste, and in quantities much larger than the main products. The largest share among them belongs to the poultry litter. Beginning from the poultry house, litter becomes a source of unpleasant odours, toxic gases emission (ammonia, hydrogen sulphide) and a favourable environment for the development of pathogenic microorganisms. Therefore, in order to protect human and poultry health, protect the environment, obtain high quality raw materials for processing into organic or organic-mineral fertilizers, it is necessary to develop the measures aimed at minimizing the negative impact of litter on the microclimate of the poultry (Palii et al., 2019). The high humidity of the litter causes the accelerated development of the anaerobic process, the conversion of nitrogen compounds into ammonia. As a result, the microclimate in the poultry house deteriorates significantly and the quality of the litter as a raw material for fertilizer production, it becomes a favourable environment for the propagation of pathogenic microflora and harmful insects. To reduce the negative impact on the microclimate in the poultry house, it is necessary to create the conditions under which the ammonia content in the air of the poultry house will decrease (Fernanda et al., 2017; Ishchenko, 2019). All chemicals that are added to reduce ammonia emissions can be divided into three categories: 1 - substances with oxidizing actions that reduce the $\mathrm{pH}$ of the litter and thus inhibit the growth of bacteria that transform the nitrogenous compounds of the litter into ammonia; 2 - adsorbents that adsorb ammonia and moisture, thereby reducing the emission of ammonia; 3 - substances that stimulate or inhibit the development of certain groups of 
microorganisms and the action of enzymes (Saeed et al., 2018). In turn, among the substances of the first category are acids, alkali-reactive salts and substances that contribute to the acidity of the material.

The most commonly used acid for the treatment of litter in order to reduce ammonia emission are hydrochloric, nitric, sulphuric, phosphoric and lactic acid. Phosphoric acid is quite effective and relatively safe to use, but it is expensive. Sulphuric, nitric and hydrochloric acids are cheaper but dangerous to use and cause corrosion (Broucek \& Bohuslav, 2015; Garcia-Palacios et al., 2016). Decreases in the $\mathrm{pH}$ of litter and ammonia emissions when using alkali-reactive salts have been determined by studies (Payne et al., 2019). At the same time, it is noted that they are less effective in reducing the litter $\mathrm{pH}$ and emission of ammonia than acids, although they are safer to use (Kim \& Choi, 2009). When using aluminium sulphate and ferrous sulphate, ammonia emission decreased by $99 \%$ and $58 \%$, respectively (Dunlop et al., 2016; Huff et al., 1996). An alternative to acids is the addition to the litter of certain carbohydrates that stimulate the development of anaerobic organisms that produce organic acids (Yadav \& Garg, 2009). The addition of sucrose for $11 \%$ by weight of the litter allows to reduce the $\mathrm{pH}$ of the material to $3.5 \%$ and the ammonia emission by $98 \%$. Other researchers used milled wheat, grinded potatoes and glucose with the addition of lactic acid-producing bacteria (Adeli et al., 2008).

A large number of substances can adsorb $\mathrm{NH}_{3}, \mathrm{NH}_{4}^{+}$, or both. The most widespread of these substances were zeolites (clinoptilolites) and peat. Zeolites are a natural aluminosilicate material with high adsorption capacity. There are about 50 varieties of zeolites. They have some differences in the ability to adsorb certain substances (Miles et al., 2011; Waqas et al., 2018). The results of the use of zeolites to reduce ammonia emissions are also quite controversial. In the experiment that studied the effect of enrichment of the litter bedding with natural zeolite in the amount of $1 \mathrm{~kg} / \mathrm{m}^{2}$ of the floor in the poultry house on the emission of ammonia emission and microclimate in the poultry house, it was found that the ammonia content of the air of the poultry house decreased by of $40 \%$ on average (Li et al., 2008).

In two separate experiments, the effect of zeolite on the ammonia emission was studied: first - by adding it to the composition of the litter bedding in the amount of $5 \mathrm{~kg} / \mathrm{m}^{2}$; second - the introduction into the complex feed in the amount of $10 \%$. In the first case, the ammonia emission was reduced by $35 \%$, in the second case - by $8 \%$ (Loch et al., 2011). Peat can adsorb ammonia up to $2.5 \%$ of its mass, and water 15-20 times its own mass (Koutcheiko et al., 2007). The benefits of using zeolite and peat for ammonia adsorption are that they are safe to use and do not harm when using manure as a fertilizer. Ammonia emission in the poultry house also decreases when such substances as paraformaldehyde, acetic and propionic acids are added to the litter bedding, as well as antibiotics that inhibit the development of anaerobic microflora (Casey et al., 2010).

The studies of the impact of litter treatment with a mixture of sodium sulphate hydrogen $93.5 \%$ and sodium sulphate $6.5 \%$ added in an amount of $245 \mathrm{~g} / \mathrm{m}^{2}$ of the poultry floor showed that for 48 days of broiler cultivation, the ammonia content in the air of the poultry houses treated litter bedding was 19.0-2.8 times lower than in the premises with untreated one. The litter treatment did not adversely affect the physiological state of the poultry. The live weight of broilers aged 49 days in the poultry house with treated litter was $2312 \mathrm{~g}$, with untreated one - $2204 \mathrm{~g}$ ( $\mathrm{Li}$ et al., 2014). In addition to the substances that contribute to the reduction of the conversion of nitrogen in the litter into ammonia form, substances of oxidative action, which react with ammonia and turn it into less harmful substances, are used. Among them, the most famous are potassium permanganate $\left(\mathrm{KMnO}_{4}\right)$, hydrogen peroxide $\left(\mathrm{H}_{2} \mathrm{O}_{2}\right)$ and ozone $\left(\mathrm{O}_{3}\right)$. Potassium permanganate is used in the amount of 250-500 mg/l of litter, hydrogen peroxide - 50-100 mg/l and ozone - $1 \mathrm{~g} / \mathrm{l}$. However, their duration is short. In addition, the use of ozone, despite the high efficiency of this reagent, requires strict control of the air content and special distribution systems, which limits its application in practice (Bolan et al., 2010; Oliveira et al., 2004; Ravindran \& Mnkeni, 2016).

The researchers (Al-Homidan et al., 2003; Ishchenko et al., 2019; Moore et al., 2000), analysing various ways to reduce ammonia emissions in poultry houses, note that despite the large number of chemical reagents that can be used for the reduction of ammonia emissions from litter, further research is needed in this direction to select an environmentally friendly and inexpensive reagent. Analysing the foresaid, it can be noted that the proposed reagents and methods of their use are acceptable, mainly when keeping the poultry on the litter bedding. Techniques for reducing ammonia emissions in the poultry houses with cage batteries have not been sufficiently elaborated and special research is needed in this direction.

\section{Material and Methods}

The purpose of the study was to investigate the microclimate parameters in the poultry house when adding various reagents and zeolite onto the belt conveyors of cage batteries.

The experiment was conducted in the cold period of the year in three premises $3 \times 4 \times 2.8 \mathrm{~m}$ in size with autonomous ventilation systems, each of which contained a 4-tier cage battery with a litter removal belt system designed for 192 egg-laying hens. The cage density of the poultry was $512.2 \mathrm{~cm}^{2} /$ head. A standard for the cold period of the year exchange rate of $0.7 \mathrm{~m}^{3} / \mathrm{h}$ per $1 \mathrm{~kg}$ of live weight of the bird was maintained in the premises. The egg-laying hens of Lohmann Brown crossbreed were used.

Two of the premises were experimental. To reduce the emission of ammonia from the litter on the conveyor belts of the litter removal system, certain substances were applied: zeolite, phosphogypsum and superphosphate -0.6 and $0.3 \mathrm{~kg} / \mathrm{m}^{2}$ of the belt, aluminium chloride and ferrous sulphate -0.2 and $0.1 \mathrm{~kg} / \mathrm{m}^{2}$ of the belt. The duration of accumulation of litter on the conveyor belt was seven days, after which it was removed from the premises. The duration of studies with each substance was three cycles of litter removal or 21 day. The third room was control. No special ammonia reduction agents were used in it. Other parameters of keeping egg-laying hens in the control poultry house and in the test poultry house were similar. During the test period, the microclimate parameters (temperature and relative humidity, ammonia, carbon dioxide and hydrogen sulphide content in the air), chemical composition of the litter after seven days of accumulation (moisture and nitrogen content) were determined in the premises. Each cycle sample of fresh litter was taken in every room, and three samples were taken after seven days of accumulation.

\section{Results and Discussion}

A possible way of solving the issue of reducing the emission of toxic gases, in particular ammonia in the air of poultry houses when keeping egg-laying hens in cage batteries, by considering the application of various adsorbents or chemical reagents was considered. The method was taken as a basis in the direction of developing rational modes of its application.

The main results of the study of the impact of various reagents and absorbents at the doses used on ammonia emissions and the microclimate in the poultry house in general are given in Tables 1-5. 
Table 1. Microclimate in the poultry house when applying zeolite on the litter removal belt conveyors.

Microclimate parameter

\section{Days of accumulation of litter on the belts of cage batteries}

1 3

5

\section{7}

\section{Zeolite $-600 \mathrm{~g} / \mathrm{m}^{2}$}

Air temperature, ${ }^{\circ} \mathrm{C}$

Relative humidity, \%

Ammonia content in the air, $\mathrm{mg} / \mathrm{m}^{3}$

Carbon dioxide content in the air, $\%$

Hydrogen sulphide content in the air, $\mathrm{mg} / \mathrm{m}^{3}$

Air temperature, ${ }^{\circ} \mathrm{C}$

Relative humidity, \%

Ammonia content in the air, $\mathrm{mg} / \mathrm{m}^{3}$

Carbon dioxide content in the air, \%

Hydrogen sulphide content in the air, $\mathrm{mg} / \mathrm{m}^{3}$

Air temperature, ${ }^{\circ} \mathrm{C}$

Relative humidity, \%

Ammonia content in the air, $\mathrm{mg} / \mathrm{m}^{3}$

Carbon dioxide content in the air, $\%$

Hydrogen sulphide content in the air, $\mathrm{mg} / \mathrm{m}^{3}$

$21.1 \pm 0.65$
$63.2 \pm 1.3$
$5.2 \pm$
$0.47 * * *$
0.12
$21.7 \pm 0.53$
$66.1 \pm 1.2$
$8.0 \pm$
$0.49 * * *$
0.13

Zeolite - $300 \mathrm{~g} / \mathrm{m}^{2}$
$21.8 \pm 0.56$
$64.4 \pm 1.6$
$5.2+0.63 * * *$
0.12
Control
$21.2 \pm 0.48$
$67.2 \pm 1.4$
$8.6 \pm 0.69 * *$
0.13
-
$21.3 \pm 0.52$
$65.6 \pm 1.2$
$8.3 \pm 0.52$
0.14
$21.1 \pm 0.65$
$68.4 \pm 2.1$
$11.2 \pm 0.53$
0.14

$21.3 \pm 0.76$
$70.2 \pm 2.2$
$14.9 \pm$
$0.66 * * *$
0.15

$21.9 \pm 0.73$

$67.5 \pm 2.1$

$14.3 \pm 0.73$

0.14
$21.6 \pm 0.59$
$71.9 \pm 2.2$
$18.2 \pm 0.55$
0.16
$21.5 \pm 0.73$
$69.6 \pm 1.5$
$15.7 \pm 0.67$
0.15

$21.0 \pm 0.74$

$72.3 \pm 2.7$

$18.6 \pm 0.79$

0.16

Note: * here and further $\mathrm{P} \leq 0.05 ; * * \mathrm{P} \leq 0.01 ; * * * \mathrm{P} \leq 0,001$ (compared to the control).

The experiment did not find any significant effect of the accumulation of litter on conveyor belts on indoor temperature. At the same time, with an increase in the period of accumulation of litter on the belts from one to seven days, a tendency to increase in the relative humidity of the air, carbon dioxide content, ammonia and hydrogen sulphide was observed. Thus, during 7 days, the period of accumulation of litter on conveyor belts in the control room where zeolite or other chemical agents were not used, the ammonia content in the air increased by 1.9-2.3 times, exceeding in some cases the maximum contaminant level (MCL) - $15 \mathrm{mg} / \mathrm{m}^{3}$ of the air in the poultry house. The content of carbon dioxide in the air increased to a lesser extent - by 1.15-1.6 times. The concentration of hydrogen sulphide in the premises was insignificant (below one $\mathrm{mg} / \mathrm{m}^{3}$ ). Traces of this gas were determined in some cases only in the last days of accumulation of litter. No significant effect of zeolite or the reagents used on the relative humidity was found.

In the room where zeolite was applied on the conveyor belt in an amount of $600 \mathrm{~g} / \mathrm{m}^{2}$ of its area, ammonia content in the air decreased by 1.6 times on the $1^{\text {st }}$ day of litter accumulation, and by 1.25 times on the $7^{\text {th }}$ day, not exceeding MCL for all 7 days. The reduction of ammonia emissions in the room where zeolite was used in the amount of $300 \mathrm{~g} / \mathrm{m}^{2}$ on the conveyor belt was less significant. If on the $1^{\text {st }}$ day the emission reduction was practically the same as with the $600 \mathrm{~g} / \mathrm{m}^{2}$ dosage, but starting from the $6^{\text {th }}$ day the ammonia concentration in the test and control rooms was almost equal.

Table 2. Microclimate in the poultry house when applying phosphogypsum on the litter removal belt conveyors.

\section{Microclimate parameter}

Air temperature, ${ }^{\circ} \mathrm{C}$

Relative humidity, $\%$

Ammonia content in the air, $\mathrm{mg} / \mathrm{m}^{3}$

Carbon dioxide content in the air, $\%$

Hydrogen sulphide content in the air $\mathrm{mg} / \mathrm{m}^{3}$

Air temperature, ${ }^{\circ} \mathrm{C}$

Relative humidity, \%

Ammonia content in the air, $\mathrm{mg} / \mathrm{m}^{3}$

Carbon dioxide content in the air,\%

Hydrogen sulphide content in the air, $\mathrm{mg} / \mathrm{m}^{3}$

Air temperature, ${ }^{\circ} \mathrm{C}$

Relative humidity, \%

Ammonia content in the air, $\mathrm{mg} / \mathrm{m}^{3}$

Carbon dioxide content in the air, \%

Hydrogen sulphide content in the air, $\mathrm{mg} / \mathrm{m}^{3}$

\section{Days of accumulation of litter on the belts of cage} batteries

\section{Phosphogypsum - $600 \mathrm{~g} / \mathrm{m}^{2}$}

5

$21.3 \pm 0.43$
$68.3 \pm 1.4$
$10.9 \pm 0.67^{* * *}$
0.15

$21.3 \pm 0.43$

$21.5 \pm 0.49$

$64.5 \pm 1.1$

$3.5 \pm 0.39 * * *$

0.13
$21.3 \pm 0.45$
$64.8 \pm 1.5$
$6.4 \pm 0.54 * * *$
0.15

Phosphogypsum - $300 \mathrm{~g} / \mathrm{m}^{2}$

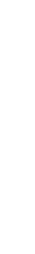

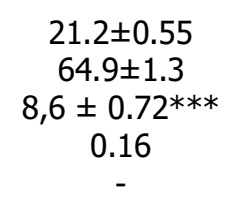

Control

$$
\begin{gathered}
21.9 \pm 0.76 \\
68.3 \pm 1.9 \\
12.9 \pm 0.64 \\
0.16
\end{gathered}
$$$$
\begin{gathered}
21.8 \pm 0.63 \\
65.7 \pm 1.8 \\
11.6 \pm 0.49 \\
0.16 \\
-
\end{gathered}
$$
$21.9 \pm 0.65$
$68.7 \pm 1.9$
$14.2 \pm 0.69$
0.17

-
$21.1 \pm 0.54$
$69.1 \pm 1.9$
$14.3 \pm 0.72$
0.15

$7.4 \pm 0.52$

0.13
$21.6 \pm 0.67$

$69.1 \pm 2.3$

$15.2 \pm 0.69$

0.17
$21.3 \pm 0.72$
$69.6 \pm 2.3$
$15.7 \pm 0.57$
0.17

1 
The application of phosphogypsum on conveyor belt in the amount of $600 \mathrm{~g} / \mathrm{m}^{2}$ of its area provided a reduction of ammonia emission by 2.1-1.1 times. During the period of study, as well as with the application of zeolite, there was a decrease in the effectiveness of this reagent, but on the fifth day, the content of ammonia in the experimental room was still 1.3 times lower than in the control one. When using phosphogypsum in the amount of $300 \mathrm{~g} / \mathrm{m}^{2}$ of the conveyor area, the content of ammonia in the room was reduced to a lesser extent, the duration of the effective action of the reagent was also less.

Table 3. Microclimate in the poultry house when applying superphosphate on the litter removal belt conveyors.

\section{Microclimate parameter}

Air temperature, ${ }^{\circ} \mathrm{C}$

Relative humidity, \%

Ammonia content in the air, $\mathrm{mg} / \mathrm{m}^{3}$

Carbon dioxide content in the air, \% Hydrogen sulphide content in the air, $\mathrm{mg} / \mathrm{m}^{3}$

Air temperature, ${ }^{\circ} \mathrm{C}$

Relative humidity, $\%$

Ammonia content in the air, $\mathrm{mg} / \mathrm{m}^{3}$

Carbon dioxide content in the air, \%

Hydrogen sulphide content in the air, $\mathrm{mg} / \mathrm{m}^{3}$

Air temperature, ${ }^{\circ} \mathrm{C}$

Relative humidity, $\%$

Ammonia content in the air, $\mathrm{mg} / \mathrm{m}^{3}$

Carbon dioxide content in the air,\%

Hydrogen sulphide content in the air, $\mathrm{mg} / \mathrm{m}^{3}$

\section{Days of accumulation of litter on the belts of cage} batteries

1 3 Superphosphate $-600 \mathrm{~g} / \mathrm{m}^{2}$

$\begin{array}{cccc}16.5 \pm 0.57 & 17.1 \pm 0.68 & 17.3 \pm 0.43 & 17.1 \pm 0.54 \\ 62.5 \pm 1.9 & 65.7 \pm 1.5 & 67.3 \pm 2.4 & 68.0 \pm 1.8 \\ 3.7 \pm 0.44^{* * *} & 6.3 \pm & 11.0 \pm 0.75^{*} & 14.5 \pm 0.52 \\ 0.10 & 0.66^{* * *} & & \\ & 0.12 & 0.12 & 0.13\end{array}$

Superphosphate $-300 \mathrm{~g} / \mathrm{m}^{2}$

$\begin{array}{cccc}17.1 \pm 0.48 & 17.2 \pm 0.55 & 17.9 \pm 0.76 & 17.6 \pm 0.67 \\ 63.3 \pm 1.6 & 64.1 \pm 1.3 & 67.2 \pm 1.9 & 69.1 \pm 2.3 \\ 4.1 \pm 0.48^{* * *} & 8.4 \pm 0.72^{*} & 12.0 \pm 0.64 & 14.8 \pm 0.69 \\ 0.11 & 0.11 & 0.12 & 0.13 \\ - & - & - & - \\ \text { Control } & & & \\ 16.8 \pm 0.54 & 17.8 \pm 0.72 & 17.7 \pm 0.63 & 17.9 \pm 0.78 \\ 62.7 \pm 2.4 & 64.9 \pm 1.7 & 67.3 \pm 2.1 & 69.4 \pm 2.3 \\ 7.7 \pm 0.66 & 10.7 \pm 0.63 & 13.2 \pm 0.64 & 14.9 \pm 0.67 \\ 0.10 & 0.12 & 0.12 & 0.13 \\ - & - & 1 & 1\end{array}$

The application of superphosphate on litter removal conveyor belts in the mentioned above quantities helped to reduce the ammonia content in the air of the poultry house almost to the same extent as with the application of phosphogypsum - by 2.1 times on the $1^{\text {st }}$ day and by 1.03 times on the $7^{\text {th }}$ day the accumulation of litter. The effective time of this reagent was also close in importance.

Table 4. Microclimate in the poultry house when applying aluminium chloride on the litter removal belt conveyors.

\section{Microclimate parameter}

Air temperature, ${ }^{\circ} \mathrm{C}$

Relative humidity, $\%$

Ammonia content in the air, $\mathrm{mg} / \mathrm{m}^{3}$

Carbon dioxide content in the air, \%

Hydrogen sulphide content in the air, $\mathrm{mg} / \mathrm{m}^{3}$

Air temperature, ${ }^{\circ} \mathrm{C}$

Relative humidity, \%

Ammonia content in the air, $\mathrm{mg} / \mathrm{m}^{3}$

Carbon dioxide content in the air, \%

Hydrogen sulphide content in the air, $\mathrm{mg} / \mathrm{m}^{3}$

Air temperature, ${ }^{\circ} \mathrm{C}$

Relative humidity, \%

Ammonia content in the air, $\mathrm{mg} / \mathrm{m}^{3}$

Carbon dioxide content in the air, \%

Hydrogen sulphide content in the air, $\mathrm{mg} / \mathrm{m}^{3}$

Days of accumulation of litter on the belts of cage

\section{1}

$\mathrm{AlCl}_{3}-200 \mathrm{~g} / \mathrm{m}^{2}$

$16.2 \pm 0.59$

$62.7 \pm 1.3$

$1.6 \pm 0.53^{* * *}$

0.10

$\mathrm{AlCl}_{3}-100 \mathrm{~g} / \mathrm{m}^{2}$

$16.1 \pm 0.57$

$63.4 \pm 1.9$

$1.7 \pm 0.65^{* * *}$

0.10

Control

$16.4 \pm 0.72$

$63.9 \pm 2.1$

$6.5 \pm 0.69$

0.10
$17.4 \pm 0.56$

$65.2 \pm 1.4$

$2.9 \pm$

$0.67 * * *$

0.13

\section{5}

$16.9 \pm 0.58$
$66.9 \pm 2.1$
$8.6 \pm$
$0.65^{* * *}$
0.13

$16.5 \pm 0.66$

$66.8 \pm 2.1$

$11.7 \pm 0.59$

0.14
$65.7 \pm 1.7$

$0.52 * * *$

0.13
$17.6 \pm 0.48$
$64.8 \pm 1.6$
$8.7 \pm 0.56$
0.13

$17.5 \pm 0.69$

$66.9 \pm 2.3$

$12.9 \pm 0.67$

0.13
$17.3 \pm 0.61$

$68.5 \pm 1.3$

$14.0 \pm 0.52 *$

0.14

$17.5 \pm 0.68$

$68.5 \pm 2.2$

$14.8 \pm 0.61$

0.15
$17.1 \pm 0.72$

$67.8 \pm 2.1$

$14.9 \pm 0.63$

0.16

Aluminium chloride and ferrous sulphate were used in smaller doses than other adsorbents or reagents, but in the first five days of litter accumulation they provided a relatively significant reduction in the ammonia content in the air of the poultry house: ferrous 
sulphate at a dose of $200 \mathrm{~g} / \mathrm{m}^{2}$ of the conveyor belt area - by 2.0-1.2 times, aluminium chloride - by $4.0-1.4$ times. At the same time, the efficacy of these reagents in the last days of litter accumulation has been markedly reduced. The use of aluminium chloride and ferrous sulphate $100 \mathrm{~g}$ for $/ \mathrm{m}^{2}$ of the conveyor belt provided a proper reduction of indoor ammonia content for the first 3-4 days only.

Table 5. Microclimate in the poultry house when applying ferrous sulphate on the litter removal belt conveyors.

\section{Microclimate parameter}

Air temperature, ${ }^{\circ} \mathrm{C}$

Relative humidity, $\%$

Ammonia content in the air, $\mathrm{mg} / \mathrm{m}^{3}$

Carbon dioxide content in the air, $\%$ Hydrogen sulphide content in the air, $\mathrm{mg} / \mathrm{m}^{3}$

Air temperature, ${ }^{\circ} \mathrm{C}$

Relative humidity, $\%$

Ammonia content in the air, $\mathrm{mg} / \mathrm{m}^{3}$

Carbon dioxide content in the air, $\%$

Hydrogen sulphide content in the air, $\mathrm{mg} / \mathrm{m}^{3}$

Air temperature, ${ }^{\circ} \mathrm{C}$

Relative humidity, $\%$

Ammonia content in the air, $\mathrm{mg} / \mathrm{m}^{3}$

Carbon dioxide content in the air, $\%$

Hydrogen sulphide content in the air, $\mathrm{mg} / \mathrm{m}^{3}$

\section{Days of accumulation of litter on the belts of cage batteries} $\mathrm{FeSO}_{4} \times 7 \mathrm{H}_{2} \mathrm{O}-200 \mathrm{~g} / \mathrm{m}^{2}$

$17.2 \pm 0.65$
$65 \pm 1.9$
$3.9 \pm$
$0.43^{* * *}$
0.09

3

$16.4 \pm 0.61$

$65 \pm 1.8$

$5.9 \pm 0.53 * * *$

0.12

$-$

$$
\begin{aligned}
17.3 & \pm 0.55 \\
66 & \pm 2.1 \\
10.4 & \pm 0.59
\end{aligned}
$$

0.13
$16.9 \pm 0.55$

$68 \pm 2.1$

$67 \pm 2.3$

$12.4 \pm 0.48$

$15.3 \pm 0.59$

0.15

0.13

Control

$17.7 \pm 0.53$

$65 \pm 2.1$

$16.9 \pm 0.68$

$17.5 \pm 0.69$

$66 \pm 1.7$

$66 \pm 1.6$

$7.7 \pm 0.58$

$8.8 \pm 0.55$

$12.5 \pm 0.67$

0.13

0.13
$17.1 \pm 0.59$

$68 \pm 2.3$

$15.4 \pm 0.57$

0.14
$17.1 \pm 0.62$

$68 \pm 2.2$

$15.4 \pm 0.64$

0.15

The significant decrease in the effectiveness of the substances used to reduce ammonia emissions during the study period was, in our opinion, due not only to a decrease in their adsorption (reactivity) capacity, but also to a large extent the absence of direct contact with the upper layers of litter. Therefore, it is supposed that in the case of periodic agitation of the substrate, the reduction of ammonia emissions would be more significant. During seven days, $19.5-22.3 \mathrm{~kg}$ of fresh litter was dropped per $\mathrm{m}^{2}$ of the conveyor belt. The humidity of fresh litter was 72.7-69.4\%. After seven days of accumulation on the belts, it decreased by 8.7$12.4 \%$. The final weight of the litter was $13.8-15.3 \mathrm{~kg}$ per $\mathrm{m}^{2}$ of the conveyor belt. No significant effect on the moisture content of the litter of substances used to reduce ammonia, except for zeolite, in which the moisture content of the litter was reduced by 2.1$3.4 \%$, was determined; but in this case, the difference with the control group was also statistically insignificant. The nitrogen losses from the litter within seven days of accumulation were 3.2-6.9\%, while in the experimental premises (when used to reduce ammonia emissions of various substances) they were lower than in the control ones (Table 6).

Table 6. Nitrogen content in the litter (in terms of dry substance).

\section{Substance and dose used to reduce ammonia emissions}

Zeolite $\left(600 \mathrm{~g} / \mathrm{m}^{2}\right)$

Zeolite $\left(300 \mathrm{~g} / \mathrm{m}^{2}\right)$

Not applied (first control)

Phosphogypsum $\left(600 \mathrm{~g} / \mathrm{m}^{2}\right)$

Phosphogypsum $\left(300 \mathrm{~g} / \mathrm{m}^{2}\right)$

Not applied (second control)

Superphosphate $\left(600 \mathrm{~g} / \mathrm{m}^{2}\right)$

Superphosphate $\left(300 \mathrm{~g} / \mathrm{m}^{2}\right)$

Not applied (thir control)

Aluminium chloride $\left(200 \mathrm{~g} / \mathrm{m}^{2}\right)$

Aluminium chloride $\left(100 \mathrm{~g} / \mathrm{m}^{2}\right)$

Not applied (fourth control)

Ferrous sulphate $\left(200 \mathrm{~g} / \mathrm{m}^{2}\right)$

Ferrous sulphate $\left(100 \mathrm{~g} / \mathrm{m}^{2}\right)$

Not applied (fourth control)

Nitrogen content in the litter, \%

\section{Fresh litter}

$4.87 \pm 0.032$

$4.86 \pm 0.036$

$4.89 \pm 0.039$

$4.92 \pm 0.028$

$4.88 \pm 0.025$

$4.94 \pm 0.036$

$4.83 \pm 0.041$

$4.89 \pm 0.037$

$4.88 \pm 0.029$

$4.86 \pm 0.032$

$4.84 \pm 0.031$

$4.86 \pm 0.026$

$4.81 \pm 0.028$

$4.74 \pm 0.039$

$4.87 \pm 0.034$

\section{Litter after 7 days accumulation}

(\% of content in fresh litter)

$4.68+0.029(96.1 \%)^{* *}+$

$4.61+0.027(94.9 \%) * * *$

$4.58+0.033(93.7 \%) * * * *$

$4.71+0.031(95.9 \%)^{* * *}+$

$4.65+0.039(95.3 \%)^{* * *}$

$4.61+0.033(93.4 \%)^{* * *}$

$4.67+0.023(96.6 \%)^{* *}+$

$4.59+0.034(93.9 \%)^{* * *}$

$4.55+0.031(93.2 \%)^{* * *}$

$4.70+0.037(96.8 \%)^{*}++$

$4.60+0.027(95.0 \%)^{* * *}$

$4.52+0.038(93.1 \%)^{* * *}$

$4.65+0.034(96.7 \%)^{*}+$

$4.52+0.045(95.4 \%)^{* *}$

$4.54+0.041(93.3 \%)^{* * *}$

Note: * - $\mathrm{P} \leq 0.05 ; * *-\mathrm{P} \leq 0.01 ; * * *-\mathrm{P} \leq 0.001$ (compared to fresh litter); ++ - $\mathrm{P} \leq 0.01 ;+++-\mathrm{P} \leq 0.001$ (compared to the control for the given substance).

It should be noted that the given doses of reagents for the binding of ammonia are calculated based on the condition of full reaction of the material. At the same time, the real conditions for the interaction of the reagent and ammonia on the litter removal conveyor belts 
are significantly different from the optimal ones. As shown by previous studies (Ishchenko et al., 2019), when using cage batteries equipped with ducts, on the seventh day of accumulation of litter, the ammonia content in the air of the poultry house was $17.1 \mathrm{mg} / \mathrm{m}^{3}$ of air, i.e. exceeded MCL by $2.1 \mathrm{mg} / \mathrm{m}^{3}$. When using cage batteries without air ducts in the cold season, the concentration of ammonia in the air of the poultry house reached $21 \mathrm{mg} / \mathrm{m}^{3}$, i.e. exceeded MCL by $6 \mathrm{mg} / \mathrm{m}^{3}$ of the air. On this basis, the techniques proposed for reducing the content of toxic gases in the air should, at a minimum, reduce it to the level below MCL. Based on the standard air exchange in the poultry house in the cold season which is $0.7 \mathrm{~m}^{3} / \mathrm{h}$ of the air per $\mathrm{kg}$ of live weight of the bird, the total air exchange in the poultry house will be $14700 \mathrm{~m}^{3} / \mathrm{h}$ for every 10 thousand egg laying hens weighing of $2.1 \mathrm{~kg}$ on average; thus, with the use of cage batteries with ducts, it is necessary to bind not less than $30 \mathrm{~g}$ of ammonia per hour, and with the application of cage batteries without the air ducts $-88 \mathrm{~g}$ of ammonia per hour, or 0.72 and $2.1 \mathrm{~kg} /$ day, respectively.

The choice of adsorbents and chemical reagents for experiments was carried out according to the criteria of affordability in Ukraine, environmental safety, sufficient efficiency in reducing the emission of toxic gases into the air of the poultry houses. Based on this, zeolite was selected as the most promising adsorbent and phosphogypsum, superphosphate, aluminium chloride and iron sulphate as chemical reagents. Zeolites are minerals from the group of aqueous aluminosilicates of alkaline and alkaline earth elements with a tetrahedral structural framework that includes hollows occupied by cations and water molecules. Zeolites include (in \%): $\mathrm{SiO}_{2}-71.5 ; \mathrm{Al}_{2} \mathrm{O}_{3}-13.1 ; \mathrm{Fe}_{2} \mathrm{O}_{3}-$ 0.9; $\mathrm{MnO}$ - 0.19; $\mathrm{MgO}$ - 1.07; $\mathrm{CaO}-2.1 ; \mathrm{Na}_{2} \mathrm{O}-2.41 ; \mathrm{K}_{2} \mathrm{O}-2.96 ; \mathrm{P}_{2} \mathrm{O}_{5}-0.033$, as well as trace amounts of sulphur, nickel, vanadium, molybdenum, copper, tin, cobalt and zinc. Dry zeolite is a microporous crystalline sponge with a pore volume of up to $50 \%$ by volume of the substance and is a highly active adsorbent (Eleroglu \& Yalcin, 2005). The diameter of the inlets of the sponge ranges from 0.3 to $1.0 \mathrm{~nm}$ (depending on the type of zeolite). Thus, molecular sieve selection of molecules from gas takes place. The ability of zeolites to adsorb gases $\left(\mathrm{CO}_{2}, \mathrm{SO}_{2}, \mathrm{H}_{2} \mathrm{~S}, \mathrm{Cl}_{2}, \mathrm{NH}_{3}\right)$ from liquid and liquid media was determined (Turan, 2008). Applying zeolites into the soil has a double benefit: Provides prolonged action of the applied fertilizer and prevents from leaching of useful substances.

Phosphogypsum is a waste of sulphuric acid and melange processing of phosphate raw material (apatite concentrate, etc.) into mineral fertilizers, phosphoric acid and the like. According to the State Standard of Ukraine (DSTU Б B.2.7-1-93), up to 90\% of its composition (in terms of dry substance) is $\mathrm{CaSO}_{4}$. In addition, phosphogypsum contains up to $1.5 \%$ of phosphates (in terms of $\mathrm{P}_{2} \mathrm{O}_{5}$ ), and a number of other chemical elements. It is a powder of grey colour with moisture content up to $25 \%$. Bulk mass at moisture content of $20 \%$ is $1.25-1.40 \mathrm{~g} / \mathrm{cm}^{3}$ (Do et al., 2005). Phosphogypsum is recommended to be used for the enrichment of soils with phosphorus and their gypsuming. The effect of phosphogypsum on the decay is determined by the fact that calcium sulphate binds ammonia to ammonium sulphate: $\mathrm{CaSO}_{4}+2 \mathrm{H}_{2} \mathrm{O}+2 \mathrm{NH}_{3}=\mathrm{Ca}(\mathrm{OH})_{2}+\left(\mathrm{NH}_{4}\right)_{2} \mathrm{SO}_{4}$. The binding of $1 \mathrm{~kg}$ of ammonia nitrogen requires $6.14 \mathrm{~kg}$ of $\mathrm{CaSO}_{4} \cdot 2 \mathrm{H}_{2} \mathrm{O}$. As phosphogypsum contains about $90 \%$ of $\mathrm{CaSO}_{4} \cdot 2 \mathrm{H}_{2} \mathrm{O}$, as mentioned above, binding of $1 \mathrm{~kg}$ of ammoniac nitrogen requires $7.2 \mathrm{~kg}$ of phosphogypsum (Moalla et al., 2017).

Superphosphate is a common phosphate fertilizer in Ukraine. It contains 14-19.5\% of $\mathrm{P}_{2} \mathrm{O}_{5}$, a significant proportion of phosphogypsum. Dual superphosphate contains $44-48 \%$ of $\mathrm{P}_{2} \mathrm{O}_{5}$ and very little phosphogypsum. In addition to $14.0-19.5$ of $\mathrm{P}_{2} \mathrm{O}_{5}$ ammoniated superphosphate includes $1.6 \%$ of ammonia, $1.5-2.5 \%$ of manganese superphosphate and other impurities. The phosphogypsum contained in superphosphate reacts with ammonia under the scheme above and the $\mathrm{group}_{\mathrm{Ca}}\left(\mathrm{H}_{2} \mathrm{PO}_{4}\right)_{2} \mathrm{xH}_{2} \mathrm{O}$ : $\mathrm{Ca}\left(\mathrm{H}_{2} \mathrm{PO}_{4}\right)_{2}+\mathrm{H}_{2} \mathrm{O}+2 \mathrm{NH}_{3}=\mathrm{Ca}(\mathrm{OH})_{2}+2\left(\mathrm{NH}_{4}\right)\left(\mathrm{H}_{2} \mathrm{PO}_{4}\right)$ (Soliman \& Hassan, 2017).

Ferrous sulphate $\left(\mathrm{FeSO}_{4}\right)$ is also a common substance used in many industries. These are very hygroscopic light green crystals soluble in water. The aqueous solution at temperatures from 1.82 to $56.8^{\circ} \mathrm{C}$ forms heptahydrate $\mathrm{FeSO}_{4} \cdot 7 \mathrm{H}_{2} \mathrm{O}-$ blue and green crystals. The formula for the chemical reaction with ammonia is: $\mathrm{FeSO}_{4}+2 \mathrm{H}_{2} \mathrm{O}+\mathrm{NH}_{3}=\mathrm{Fe}(\mathrm{OH})_{2}+\left(\mathrm{NH}_{4}\right)_{2} \mathrm{SO}_{4}$. For binding $1 \mathrm{~kg}$ of ammonia, $4.5 \mathrm{~kg}$ of ferrous sulphate are necessary (Hajilari et al., 2019).

Aluminium chloride $\left(\mathrm{AlCl}_{3}\right)$ anhydrous is a crystalline powder of white colour, density $2440 \mathrm{~kg} / \mathrm{m}^{3}$. It is well soluble in water. $\mathrm{AlCl}_{3} \cdot 6 \mathrm{H}_{2} \mathrm{O}$ crystalline hydrate, white and yellow deliquescing crystals, precipitates from the aqueous solutions. Anhydrous aluminium chloride reacts with many inorganic substances, including ammonia and hydrogen sulphide. The chemical reaction with ammonia is as follows: $\mathrm{AlCl}_{3}+3 \mathrm{H}_{2} \mathrm{O}+3 \mathrm{NH}_{3}=\mathrm{Al}(\mathrm{OH})_{3}+3 \mathrm{NH}_{4} \mathrm{Cl}$. For binding $1 \mathrm{~kg}$ of ammonia, $2.6 \mathrm{~kg}$ of this reagent are necessary (Chung et al., 2017$)$.

A significant decrease in the effectiveness of substances used to reduce ammonia emissions during the study period was associated not only with a decrease in their adsorption (reactivity) capacity but also to a large extent a lack of direct contact with the upper layers of litter. Therefore, it is hoped that in the case of periodic agitation of the substrate, the reduction of ammonia emissions would be more significant. In our opinion, this method of reducing the ammonia emissions from the litter can be considered promising when using cage batteries without built-in ducts provided that a device for the distribution of adsorbents or reagents on the surface of litter removal belt conveyors will be developed.

\section{Conclusion}

The application of $600 \mathrm{~g} / \mathrm{m}^{2}$ of zeolite, phosphogypsum and superphosphate on the surface of litter removal belt conveyors allows to reduce ammonia content in the air of the poultry house. On first and seventh day the accumulation of litter was lower by 1.6-1.25; 2.1-1.1 and 2.1-1.03 times, respectively, and the application of $200 \mathrm{~g} / \mathrm{m}^{2}$ of iron sulphate and aluminium chloride caused the reduction by 2.0-1.2 and 4.0-1.5 times, respectively. No significant effects of adsorbent or reagent application on other microclimate parameters were found during the research. At the same time, the use of these substances contributed to some (by 3.2-6.9\%) reduction of nitrogen losses from the litter.

\section{References}

Adeli, A., Shankle, M. W., Tewolde, H., Sistani, K. R., \& Rrowe, D. E. (2008). Nutrient dynamics from broiler litter applied to no-till cotton in an upland soil. Agron. Journal, 100, 564-570.

Al-Homidan, A., Robertson, J. F., \& Petchey, A. M. (2003). Revier of the effect of ammonia and dust concentration on broiler performance. World's Poultry Science Journal, 59(3), 607-610.

Bolan, N. S., Szogi, A. A., Chuasavathi, T., Seshadri, B., Rothrock, M. J., \& Panneerselvam, P. (2010). Uses and management of poultry litter. World's Poultry Science Journal, 66, 673-698.

Broucek, J., \& Bohuslav, C. (2015). Emission of harmful gases from poultry farms and possibilities of their reduction. Ekológia (Bratislava), 34(1), 89-100. doi:10.1515/eko-2015-0010.

Casey, K. D., Gates, R. S., Shores, R. C., Thomas, D., \& Harris, D. B. (2010). Ammonia emissions from a U.S. broiler house-comparison of concurrent measurements using three different technologies. Journal of the Air \& Waste Management Association, 60(8), 939-948. 
Chung, T. H., Park, J. H., Kim, C. M., \& Choi, I. H. (2017). Evaluation of Aluminum Chloride As an Effective Short-Term Solution for Reducing Odor - Causing Volatile Fatty Acids in Duck Litter. Brazilian Journal of Poultry Science, 19 (3). http://dx.doi.org/10.1590/18069061-2016-0401

Do, J. C., Choi, I. H., \& Nahm, K. H. (2005). Effects of chemically amended litter on broiler performances, atmospheric ammonia concentration, and phosphorus solubility in litter. Poultry Science, 84(5), 679-686. https://doi.org/10.1093/ps/84.5.679

Dunlop, M. W., Blackall, P. J., \& Stuetz, R. M. (2016). Odour emissions from poultry litter - A review litter properties, odour formation and odorant emissions from porous materials. Journal Environ Manage., 177, 306-319. doi:10.1016/j.jenvman.2016.04.009

Eleroglu, H., \& Yalcin, H. (2005). Use of natural zeolite-supplemented litter increased broiler production. South African Journal of Animal Science, 35(2), 90-97.

Fernanda, C. S., Iida, F. F. T., Jagir, N. S., \& Baptista, F. J. F. (2017). Gas emission in the poultry production. Journal of Animal Behaviour and Biometeorology, 5(2), 49-55. doi:10.14269/2318-1265/jabb.v5n2p49-55

Garcia-Palacios, P., G. McKle, B., Handa, I. T., Frainer, A., \& Hattenschwiler, S. (2016). The importance of litter traits and decomposers for litter decomposition: a comparison of aquatic and terrestrial ecosystems within and across biomes. Functional Ecology, 30, 819-829. doi:10.1111/1365-2435.12589

Hajilari, D., Shams, S. M., \& Ashayerizadeh, O. (2019). Effects of dietary organic and inorganic zinc and copper supplements on performance, footpad dermatitis, carcass characteristics, and blood profile of broiler chickens. Poultry Science Journal, 7(1), 15-23. doi:10.22069/psj.2019.15332.1345

Huff, W. E., Moore J. P. A., Balog, J. M., Bayyari, G. R., \& Rath, N. C. (1996). Evaluation of the toxicity of alum (aluminum sulfate) in young broiler chicks. Poultry Science, 75(11), 1359-1364. doi:10.3382/ps.0751359

Ishchenko, K. V. (2019). Investigation of the parameters of the microclimate of chickens and the chemical composition of the hens litter for the use of cell batteries with different air removal systems. Scientific and Technical Bulletin of IT NAAN, 121, 127-136. doi:10.32900/23128402-2019-121-127-136

Ishchenko, K. V., Palii, A. P., Kis, V. M., Petrov, R. V., Nagorna, L. V., Dolbanosova, R. V., \& Paliy, A. P. (2019). Investigation of microclimate parameters for the content of toxic gases in poultry houses during air treatment in the scrubber with the use of various fillers. Ukrainian Journal of Ecology, 9(2), 74-80.

Kim, Y. J., \& Choi, I. J. (2009). Effect of alum and liquid alum on $\mathrm{pH}, \mathrm{EC}$, moisture, ammonium and soluble phosphorus contents in poultry litter during short term: a laboratory experiment. Journal of Poultry Science, 46(10), 63-67.

Koutcheiko, S., Monreal, C. M., Kodama, H., McCraken, T., \& Kotlyar, L. (2007). Preparation and characterization of activated carbon derived from the thermo-chemical conversion of chicken manure. Bioresour. Technol., 98, 2459-2464. doi:10.1016/j.biortech.2006.09.038 Li, G., Li, H., Leffelaar, P.A., Shen, J., \& Zhang, F. (2014). Characterization of phosphorus in animal manures collected from three (dairy, swine, and broiler) farms in China. PLoS One. 9(7). e102698. doi:10.1371/journal.pone.0102698

Li, H., Xin, H., Liang, Y., \& Burns, R. (2008). Reduction of ammonia emissions from stored laying hen manure through topical application of zeolite, Al+Clear, Ferix-3, or poultry litter treatment. Journal of Applied Poultry Research, 17(4), 421-431. doi:10.3382/japr.2007-00076

Loch, F. C., Oliveira, M. C., Silva, D., Gonçalves, B. N., Faria, B. F., \& Menezes, J. F. (2011). Quality of poultry litter submitted to different treatments in five consecutive flocks. Revista Brasileira de Zootecnia, 40(5). http://dx.doi.org/10.1590/S1516-35982011000500013

Miles, D. M., Rowe, D. E., \& Cathcart, T. C. (2011). High litter moisture content suppresses litter ammonia volatilization. Poultry Science, 90 , 1397-1405. doi:10.3382/ps.2010-01114

Moalla, R., Gargouri, M., Khmiri, F., Kamoun, L., \& Zairi, M. (2017). Phosphogypsum purification for plaster production: A process optimization using full factorial design. Environmental Engineering Research, 23(1), 36-45. doi:https://doi.org/10.4491/eer.2017.055 Moore, J. P. A., Daniel, T. C., \& Edwards, D. R. (2000). Reducing phosphorus runoff and inhibiting ammonia loss from poultry manure with aluminum sulfate. Journal of Environmental Quality, 29(1), 29-37.

Oliveira, M. C., Ferreira, H. A., \& Cancherini, L. C. (2004). Effect of chemical conditioners on poultry litter quality. Arquivo Brasileiro de Medicina Veterinária e Zootecnia, 56(4), 536-541. http://dx.doi.org/10.1590/S0102-09352004000400016

Palii, A. P., Pylypenko, S. H., Lukyanov, I. M., Zub, O. V., Dombrovska, A. V., Zagumenna, K. V., Kovalchuk, Y. O., Ihnatieva, T. M., Ishchenko, K. V., Paliy, A. P., \& Orobchenko, O. L. (2019). Research of techniques of microclimate improvement in poultry houses. Ukrainian Journal of Ecology, 9(3), 41-51.

Payne, J. B., Watkins, S. E., Beitia, S., \& Phillips, G. K. (2019). Efficacy of Sodium Bisulfate or Sodium Chloride for Reducing Broiler House Floor Microbial Populations. The Journal of Applied Poultry Research, 28(1), 210-214. https://doi.org/10.3382/japr/pfy053

Ravindran, B., \& Mnkeni, P. N. S. (2016). Bio-optimization of the carbon-to-nitrogen ratio for efficient vermicomposting of chicken manure and waste paper using Eisenia fetida. Environ. Sci. Pollut. Res., 23(17), 16965-16976. doi:10.1007/s11356-016-6873-0

Saeed, M., Arain, M. A., Naveed, M., Alagawany, M., Abd El-Hack, M. E., Bhutto, Z. A., Bednarczyk, M., Kakar, M. U., Abdel-Latif, M., \& Chao, S. (2018). Yucca schidigera can mitigate ammonia emissions from manure and promote poultry health and production. Environ. Sci. Pollut. Res. Int., 25(35), 35027-35033. doi:10.1007/s11356-018-3546-1

Soliman, E. S., \& Hassan, R. A. (2017). Evaluation of superphosphate and meta-bisulfide efficiency in litter treatment on productive performance and immunity of Broilers Exposed to Ammonia Stress. Adv. Anim. Vet. Sci., 5(6), 253-259. http://dx.doi.org/10.17582/journal.aavs/2017/5.6.253.259

Turan, N. G. (2008). The effects of natural zeolite on salinity level of poultry litter compost. Bioresource Tecnology, 99(7), 2097-2101. doi:10.1016/j.biortech.2007.11.061

Waqas, Q., Byeong, E. M., Malinee, P., Jin, S. J., Min, H. L., Mohammad, N., \& Hyeon, T. K. (2018). Effects of an Aluminum Sulfate and Ferric Chloride Blend on Poultry Litter Characteristics in Vitro. The Journal of Applied Poultry Research, 27(1), 92-102. https://doi.org/10.3382/japr/pfx046

Yadav, A., \& Garg, V. K. (2009). Feasibility of nutrient recovery from industrial sludge by vermicomposting technology. Journal Hazard., 168(1), 262-268. doi:10.1016/j.jhazmat.2009.02.035

\section{Citation:}

A.P. Palii, I.M. Lukyanov, A.O. Kovalchuk, S.A. Denicenko, V.S. Kalabska, S.G. Ivashchenko, Y. A. Boyko, T.O. Sychova, P.V. Diachuk,

T.Y. Mitiashkina, A.P. Paliy (2019). Efficiency of various reagents on ammonia reduction in litter removal from belt conveyors for battery cages.

Ukrainian Journal of Ecology, 9(4), 571-577.

(cc) EY This work is licensed under a Creative Commons Attribution 4.0. License 